\title{
ORGANIC FERTILIZER AMENDMENTS REDUCE DISEASE SEVERITY OF Phytophthora palmivora ROOT ROT OF DUKU (Lansium domesticum) SEEDLINGS
}

\author{
Islah Hayati ${ }^{1}$, Suryo Wiyono ${ }^{2}$, Widodo $^{3}$, \& Sobir ${ }^{4}$ \\ ${ }^{1}$ Faculty of Agriculture, Universitas Jambi, Indonesia \\ Jl. Lintas Jambi-Muara Bulian Km. 15, Mendalo Darat, Muaro Jambi, Jambi 36657 \\ ${ }^{1,2,3}$ Department of Plant Protection, Faculty of Agriculture, Institut Pertanian Bogor, Indonesia \\ ${ }^{4}$ Department of Agronomy and Horticulture, Faculty of Agriculture, Institut Pertanian Bogor, Indonesia \\ Jl. Raya Dramaga, Kampus IPB Darmaga, Bogor 16680 \\ E-mail: islahsaja@gmail.com
}

\begin{abstract}
Organic fertilizer amendments reduce disease severity of Phytophthora palmivora root rot of duku (Lansium domesticum) seedlings. Phytophthora palmivora, is a deadly pathogen of duku, causing serious problem in the main production areas, especially in Jambi Province, Indonesia. The pathogen can infect duku plant in all stage of growth including seedlings. Organic fertilizer amended media might become a potential alternative option for this disease management. These studies were performed in soil media containing organic fertilizer of $0 \%, 10 \%, 20 \%, 30 \%(\mathrm{v} / \mathrm{v})$, served as treatment, and subjected to completely randomized design with 5 replications. This research found that incorporating $20 \%$ of organic fertilizer into media was able to lower disease severity by $23 \%$. The ability of organic fertilizer to increase media bacterial and maintain fungal density and increase chemicals of C-org, $\mathrm{P}, \mathrm{K}, \mathrm{Ca}, \mathrm{Mg}$ and $\mathrm{Zn}$ played important roles in reducing disease development.
\end{abstract}

Key words: bacterial density, chemicals, organic fertilizer

\section{INTRODUCTION}

Diseases caused by Phytophthora, were among the most damaging types of plant diseases, which have infected various plants in Southeast Asia (Drenth \& Sendall, 2004; Erwin \& Ribeiro, 1996). Some Phytophthora species can attack plants in all stages, including seeds. Crandall et al. (1945) found that $P$. cinnamomi Rands caused root disease in chestnut plants (Castanea spp.) Which were also found in nurseries. Ferguson \& Jeffers (1999) have detected various species of Phytophthora in ornamental plant nurseries. Furthermore, the survey conducted by Prigigallo et al. (2011), found various species of Phytophthora in ornamental plants and fruit nurseries.

Phytophthora palmivora Butler (Butler) is a dangerous disease-causing species that attacks the duku (Lansium domesticum Corr.) plants. This disease has caused a decline in the population of duku in many production centers in Jambi, and has even caused extinction in several places. The pathogen of P. palmivora is soil borne, attacking the root plants of duku. The attack can extend to the stem, causing cancer of the stem and the advanced stage causes the leaves to wither, fall and eventually the plant dies. The facts in the field show that this disease attacks more of the duku plants in the riverbank areas which often experience flooding. Duku plants can be attacked by this pathogen from the seedling stage to adulthood (Handoko, 2014).

The research regarding Phytophthora's disease in Duku is so far still limited. Meanwhile research on controlling Phytophthora root disease for other plants has been carried out. Kim et al. (1997) examined the use of various types of organic fertilizers in controlling $P$. capsici in paprika plants which showed that chitosan could reduce disease severity and increase soil microbial concentrations. While the use of other types of organic fertilizer can only increase the soil microbial population but does not affect the severity of the disease. Byrt et al. (1982) reported that organic fertilizer can influence germination and formation of cysts sporangia of $P$. cinnamomi. Different results were reported by Rangarajan et al. (2003) that commercial compost cannot cope with diseases caused by Phytophthora. The use of organic fertilizers was expected to also be able to control P. palmivora in duku plants. The purpose of this study was to evaluate environmental factors that play a role in controlling $P$. palmivora root disease in duku plants through the addition of organic fertilizers. 


\section{MATERIALS AND METHODS}

Research Site. This research was located at Mycology Laboratory and Green House of Bogor Agricultural University from December 2017 to December 2018.

Preparation of Plant. The plants used were 4 months old duku seedlings, $20 \mathrm{~cm}$ high with an average of 5 or 6 leaflets. Duku seedlings were transferred to polybags with a diameter of $25 \mathrm{~cm}$ which have been filled with planting media that has been mixed with organic fertilizer according to the treatment.

Preparation and Application of Inoculum. Pathogen isolates was taken at the duku production main area, namely in Batanghari Regency, which was located on the banks of Batanghari River, Jambi Province. The source of the inoculum was isolated from symptomatic roots and stems, and soils of duku rhizosphere. Isolation from plant samples was done by cutting the plant parts (skin, wood and roots) $1 \times 1 \mathrm{~cm}$ in size, soaking in $0.5 \%$ sodium hypochlorite solution for 10 minutes, then rinsing with sterile water, drying with sterile filter paper and placing on potato dextrose medium (PDA) (15 g agar, $40 \mathrm{~g}$ potato dextrose broth, $1000 \mathrm{~mL}$ aquadest) for further identification. Maintenance of Phytophthora was done in V8 agar media (200 ml V8, $3.5 \mathrm{~g} \mathrm{CaCO}_{3}, 20 \mathrm{~g}$ agar, $800 \mathrm{~mL}$ aquadest). Sporangia and mycelia were observed under a light microscope (BX-51, Olympus, Japan). Isolation of soil samples was carried out by the baiting method using green apples fruit. Soil sample was inserted into the $100 \mathrm{~mm}$ in diameter holes, made on apples and covered with insulating plastic. Apples were put in a clear plastic container, and were provided with wet cotton to keep the moisture, then incubated for 7 days at room temperature. Rotten apple edges was sliced and put on PDA and V8 media (Aryantha et al., 2015).

The inoculum used in this experiment was zoospores suspension with a density of $10^{5}$ zoospores/ $\mathrm{mL}$. V8 media culture of a week-old was cut into four equal parts using a sterile knife. Each piece was transferred to a sterile Petri dish, then cut into a 0.5 $\mathrm{cm}^{2}$ block. In each Petri dish sterile water was added to the surface and the block was incubated for 1 hour. Then, sterile water was added until it exceeds the agar surface, the Petri dish was incubated at $28{ }^{\circ} \mathrm{C}$ for 24 hours in light conditions to trigger formation of sporangia. In order for zoospores to initiate, the cup was incubated at $4{ }^{\circ} \mathrm{C}$ for 2 hours (Walker \& Bosland, 1999). Zoospores were calculated with a haemocytometer as inoculum source to drain into soil media.
Experimental Design and Data Processing. The study consisted of one factor, namely the level of organic fertilizer amendments in seedling media of $0 \%$ (control), $10 \%, 20 \%, 30 \%,(\mathrm{v} / \mathrm{v})$. Pathogen inoculation was done after the seedling have adapted well in the media, which was 2 months after planting. The research was arranged based on a completely randomized design with five replications, in which each replication consisted of five plants. Duku seedlings were planted in polybags with a diameter of $25 \mathrm{~cm}$. Comparison of disease severity, soil microbial concentration, and plant growth were analyzed for variance and tested further with Student Newman Keul at $\alpha=0.05$.

\section{Variables observed}

Severity of disease. Evaluation was carried out on the affected root at the end of the observation. Disease severity was calculated from the percentage of roots experiencing necrosis and based on scoring. The scoring severity of the disease was calculated based on a formula (Cooke, 1998):

$$
\mathrm{KP}=\frac{\sum_{1}^{4} \text { ni.v }}{\mathrm{N} . \mathrm{V}} \times 100 \%,
$$

$\mathrm{KP}=$ disease severity

$\mathrm{ni}=$ number of infected plants in the i score

vi $=$ the value of the i-score

$\mathrm{N}=$ number of plants observed

$\mathrm{V}=$ highest score on scoring scale

The scoring of the severity of root rot was as follows (Table 1).

Microbial density in the growing media. Microbial density was calculated using serial dilution method. A total of $10 \mathrm{~g}$ of soil was added to $90 \mathrm{~mL}$ of sterile distilled water in Erlenmeyer, shaken with a shaker for thirty minutes until it formed a suspension. This suspension was then diluted serially. A total of $100 \mu 1$ of suspension, starting from 1:100 was taken using a micropipet, and dispersed on the martin (peptone $20 \mathrm{~g}$, dextrose $10 \mathrm{~g}, \mathrm{KH}_{2} \mathrm{PO}_{4} .7 \mathrm{H}_{2} \mathrm{O} 1 \mathrm{~g}, \mathrm{MgSO}_{4} .7 \mathrm{H}_{2} \mathrm{O} 0.5 \mathrm{~g}$, rose bengal $1 \% 3.3 \mathrm{~mL}$, agar $20 \mathrm{~g}$, streptomycin $50 \mathrm{mg}$ ) and nutrient agar medium (NA) (10 g beef extract in $500 \mathrm{~mL}$ aquadest) on a petri dish, to obtain fungi and bacteria, respectively.

Soil chemical properties. Soil chemistry tested were $\mathrm{pH}, \mathrm{CEC}, \mathrm{C}$-organic, macro nutrient content (N, P, K) and micro (Mn, $\mathrm{Ca}, \mathrm{Mg}, \mathrm{Zn}$ ).

Plant growth and physiology. Plant growth measured was height, leaf length and leaf width. Chlorophyll 
content was one of the variable measurements of plant physiology, so that the content of leaf pigments can provide an overview of leaf physiological performance. The value of chlorophyll a, chlorophyll b, anthocyanin, carotene and total chlorophyll pigment was obtained through the measurement of spectral reflectance using the pigment estimation method according to Sims \& Gamon protocols (2002). Calculations were carried out 40 days after transplanting of duku seedling in the media.

\section{RESULTS AND DISCUSSION}

Severity of Disease. Organic fertilizers can reduce disease severity in duku seedlings caused by $P$. palmivora. The higher the content of organic fertilizer in the growing media, the lower the severity of the disease. Seedlings planted on soil without addition organic fertilizer (control) have the highest disease severity, but not significantly different from seedlings in media containing $10 \%$ organic fertilizer. The severity of the disease in the seedlings of the planting medium containing $20 \%$ and $30 \%$ organic fertilizer was reduced significantly compared to the control and media with $10 \%$ organic fertilizer (Table 2 ).

Microbial Density. Organic fertilizers increase microbial abundance in growing media. The highest bacterial and fungal density was found in the media with $30 \%$ organic fertilizer, and the lowest in media without organic fertilizer (control). Bacterial density in the growing media with organic fertilizer was relatively the same but was significantly different from the media without the addition of organic fertilizer. Planting media with organic fertilizer contained higher fungus densities, but not significantly different from media without addition of organic fertilizer (Table 3).

Soil Chemical Properties. In general, organic fertilizers increases the chemical properties of the soil. Nutrients that increased significantly were C-organic, $\mathrm{N}, \mathrm{P}, \mathrm{K}, \mathrm{Ca}, \mathrm{Mg}$ and $\mathrm{Zn}$ (Figure 1) showing that organic fertilizer used was a good source of nutrients for plants, especially for macro nutrients, $\mathrm{N}, \mathrm{P}$, and $\mathrm{K}$, and micro nutrients $\mathrm{Ca}, \mathrm{Mg}$ and $\mathrm{Zn}$.

Table 1 . The severity scoring of duku root rot

\begin{tabular}{cl}
\hline Scoring & \multicolumn{1}{c}{ Scoring remarks } \\
\hline 1 & lateral and primary root, healthy \\
2 & $\leq 30 \%$ lateral and primary root with necrosis \\
3 & $31-60 \%$ lateral and primary roots with necrosis \\
4 & $61-90 \%$ lateral and primary roots with necrosis \\
5 & $\geq 91 \%$ root system with necrosis and/or plants dead \\
\hline
\end{tabular}

Table 2. Severity of disease in various organic fertilizer treatments

\begin{tabular}{ccc}
\hline \multirow{2}{*}{ Treatment of organic fertilizer $(\%-\mathrm{v} / \mathrm{v})$} & \multicolumn{2}{c}{ Severity of disease $(\%)$ based on } \\
\cline { 2 - 3 } & Lateral root necrosis & Scoring \\
\hline 0 & $83.10 \mathrm{a}$ & $88.00 \mathrm{a}$ \\
10 & $77.30 \mathrm{a}$ & $80.00 \mathrm{ab}$ \\
20 & $59.66 \mathrm{~b}$ & $68.00 \mathrm{~b}$ \\
30 & $57.08 \mathrm{~b}$ & $66.00 \mathrm{~b}$ \\
\hline
\end{tabular}

Table 3. Microbial density in various organic fertilizer treatments

\begin{tabular}{ccc}
\hline \multirow{2}{*}{$\begin{array}{c}\text { Treatment of organic fertilizer } \\
(\%-\mathrm{v} / \mathrm{v})\end{array}$} & \multicolumn{2}{c}{ Microbial density } \\
\cline { 2 - 3 } & Bacteria $(\log \mathrm{cfu} / \mathrm{g})$ & Fungus $(\log \mathrm{cfu} / \mathrm{g})$ \\
\hline 0 & $5.10 \mathrm{a}$ & $2.24 \mathrm{a}$ \\
10 & $5.30 \mathrm{~b}$ & $2.40 \mathrm{a}$ \\
20 & $5.30 \mathrm{~b}$ & $2.48 \mathrm{a}$ \\
30 & $5.56 \mathrm{~b}$ & $2.66 \mathrm{a}$ \\
\hline
\end{tabular}


Organic fertilizers enhance plant growth. The highest plant growth was experienced by seedlings treated with $30 \%$ organic fertilizer, while the lowest growth was experienced by seedlings without organic fertilizer (Table 4).

The chlorophyll content of leaves is one of the variables to describe the physiological conditions of plants. Plants that have good growth have a higher chlorophyll content compared to plants with poor growth. In this study, the chlorophyll content of duku seedlings between treatments was not different, both for seedlings grown without organic fertilizer or seedlings with the amended organic fertilizer (Table 5). This might be because the content of organic matter in the planting media can still meet the needs of duku seeds for optimal growth.
Plant disease can occur because of an interaction between pathogens, hosts, and a supportive environment, called the disease triangle. If one of the triangular factors of the disease changes, resulting in changes in disease progression. There are several basic mechanisms by which the environment can influence the interactions between pathogens and their hosts. First, the environment can cause substantial changes in health, vulnerability or predisposition to plants. Second, the environment can directly influence the pathogens themselves. Furthermore, the environment can influence the expression of symptoms of the disease (Agrios, 2005).

Organic fertilizer amendments in this study resulted in a decrease in disease severity. This decrease in severity is caused by several things, firstly it is related
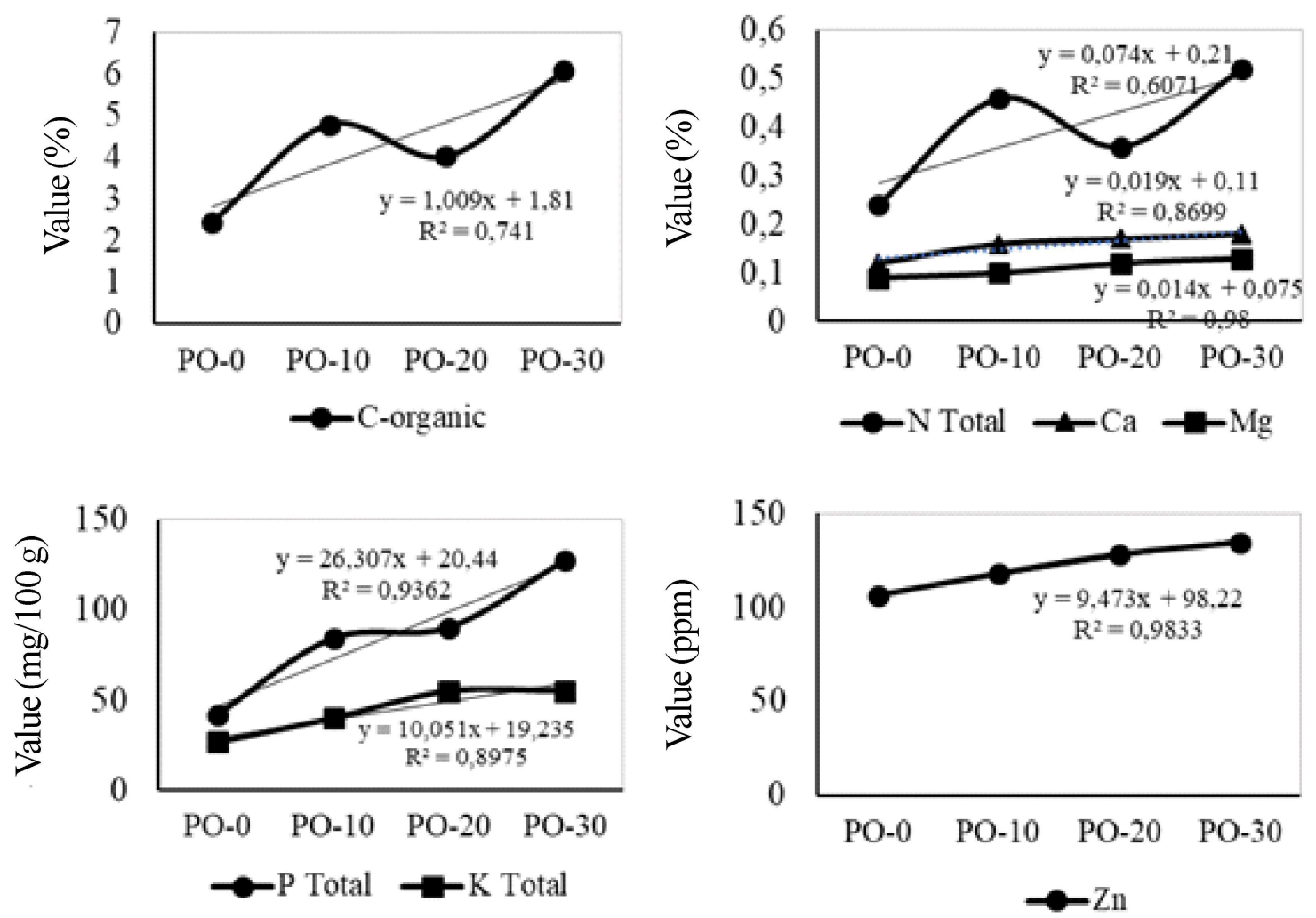

Figure 1. Effect of organic fertilizer on some soil nutrients

Table 4. Growth of duku seeds in various organic fertilizer treatments

\begin{tabular}{ccc}
\hline Treatment of organic fertilizer $(\% \mathrm{v} / \mathrm{v})$ & Height increase $(\mathrm{cm})$ & Leaf length $(\mathrm{cm})$ \\
\hline 0 & $1.98 \mathrm{a}$ & $8.41 \mathrm{a}$ \\
10 & $2.54 \mathrm{a}$ & $9.92 \mathrm{ab}$ \\
20 & $4.12 \mathrm{ab}$ & $13.86 \mathrm{~b}$ \\
30 & $6.20 \mathrm{~b}$ & $15.00 \mathrm{~b}$ \\
\hline
\end{tabular}


Table 5. Duku leaf pigment content in various organic fertilizer treatments

\begin{tabular}{cccccc}
\hline $\begin{array}{c}\text { Treatment of organic } \\
\text { fertilizer }(\% \mathrm{v} / \mathrm{v})\end{array}$ & Chlorophyl a & Chlorophyl b & Anthocyanin & Carotene & $\begin{array}{c}\text { Total } \\
\text { Chlorophyll }\end{array}$ \\
\hline 0 & $1.07 \pm 0.19$ & $0.42 \pm 0.07$ & $0.10 \pm 0.03$ & $0.39 \pm 0.07$ & $1.49 \pm 0.28$ \\
10 & $0.91 \pm 0.16$ & $0.41 \pm 0.08$ & $0.13 \pm 0.02$ & $0.36 \pm 0.06$ & $1.33 \pm 0.25$ \\
20 & $1.12 \pm 0.27$ & $0.48 \pm 0.10$ & $0.14 \pm 0.01$ & $0.41 \pm 0.08$ & $1.59 \pm 0.40$ \\
30 & $1.09 \pm 0.11$ & $0.46 \pm 0.04$ & $0.11 \pm 0.02$ & $0.42 \pm 0.04$ & $1.56 \pm 0.16$ \\
\hline
\end{tabular}

to increase plant resistance and vigor because it is influenced by the increasing chemical content of the soil. Phosphor has functions to strengthen and accelerate the root growths so that the roots can develop well, especially at the beginning of plant growth, as a result the plant can overcome stress conditions, and reduce root disease. The other factor increasing the resistance is the presence of $\mathrm{K}$ and $\mathrm{Mg}$ which are the main components of plant cell walls. Strong cell walls are mechanical protection which is the first layer in plant defense, accompanied by $\mathrm{Mg}$ which plays a role in the stability and function of cell membranes (Dordas, 2008; Huber \& Jones, 2013). The use of organic fertilizers also increase the nutrient content of $\mathrm{Zn}$ which acts as a co-factor of enzymes that plays a role in nucleic acid metabolism, cell division, and protein synthesis. Zinc can also improve plant health, productivity and resistance to pest attacks (Sarwar, 2011; Gogi et al., 2012). Fulfillment of nutrients will affect plant growth and resistance. This is in line with Handoko's report (2014) which exploratively observed the incidence of duku disease by P. palmivora was higher in soils with organic C-content and low CEC.

Organic fertilizer amendments not only provides benefits in directly increasing microbes in the media, but also it is expected that organic fertilizers can be used as a substrate for the development of beneficial microbes that are already present in the media. The increase of microbial population in this study was able to inhibit the development of pathogens through several mechanisms, such as competition, antibiotic production, parasitism, suppressive, and plant resistance induction.

Increasing $\mathrm{Ca}$ and $\mathrm{Zn}$ content in the soil are directly likely to cause a decrease in soil pathogen capability. According to Messenger et al. (2000), Ca resulted in a reduction in sporangia size and zoosporic mobility of $P$. cinnamomi. The $\mathrm{Zn}$ content has a direct toxic effect on pathogens (Graham \& Webb, 1991). In addition, organic fertilizers can have a direct effect on the pathogens of Phytophthora because of its possible antimicrobial properties, although it was not specifically examined in this research. Núñez-Zofío et al. (2011) found that the production of $\mathrm{NH} 3$ due to increase soil microbial activity was able to reduce the viability of oospore $P$. capsici in pepper plants. Organic fertilizers contain various types of amino acids, most of which are glutamic acid, aspartic acid, glycine, and alanine which are antimicrobial (Wen et al., 2007).

\section{CONCLUSIONS}

This study found that incorporating of organic fertilizer into media can reduce the severity of root rot disease caused by Phytophthora palmivora in duku seedlings. This due to changes in biological and chemical properties of soil, such as an increase in soil bacterial density and soil chemical properties (C- organic, $\mathrm{P}, \mathrm{K}$, $\mathrm{Ca}, \mathrm{Mg}$ and $\mathrm{Zn}$ ).

\section{ACKNOWLEDGMENTS}

The researchers would like to acknowledge Ministry of Research and Higher Education for financial support of this research.

\section{REFERENCES}

Aryantha IP, Santoso PJ, Pancoro A, \& Suhandono S. 2015. Identification of Pythium and Phytophthora associated with Durian (Durio sp.) in Indonesia: their molecular and morphological characteristics and distribution. Asian J. Plant Pathol. 9(2): 5971.

Agrios GN. 2005. Plant Pathology-5 th Edition. Elsevier Academic Press. Burlington.

Byrt PN, Irving HR, \& Grant BR. 1982. The effect of organic compounds on the encystment, viability and germination of zoospores of Phytophthora cinnumomi. J. Gen. Microbiol. 128(10): 23432351. 
Cooke BM. 1998. Disease assessment and yield loss. In: Jones GD (Ed.). The Epidemiology of Plant Disease. pp. 43-80. Kluwer Publishers Dordrecht.

Crandall BS, Gravatt GF, \& Ryan MM. 1945. Root disease of Castanea species and some coniferous and broadleaf nursery stocks, caused by Phytophthora cinnamomi. Phytopathol. 35: 162-180.

Drenth A \& Sendall B. 2004. Economic impact of Phytophthora diseases in Southeast Asia. In: Drenth A \& Guest DI (Eds.). Diversity and Management of Phytophthora in Southeast Asia. pp. 10-28. ACIAR Monograph 114 Canberra.

Dordas C. 2008. Role of nutrients in controlling plant diseases in sustainable agriculture. Agron. Sustain. Dev. 28(1): 33-46.

Erwin DC \& Ribeiro OK. 1996. Phytophthora Diseases Worldwide. APS Press. St. Paul (US).

Ferguson AJ \& Jeffers SN. 1999. Detecting multiple species of Phytophthora in container mixes from ornamental crop nurseries. Plant. Dis. 83:11291136.

Gogi MD, Arif JM, Asif M, Zain-ul-Abdin, Bashir MH, Ashad M, Khan MA, Abbas Q, Shahid MR, \& Anwar A. 2012. Impact of nutrient management schedules on infestation of Bemisia tabaci on yield of non-BT cotton (Gossypium hirsutum) under unsprayed condition. Pak. Entomol.34(1): 87-92.

Graham RD \& Webb MJ. 1991. Micronutrients and disease resistance and tolerance in plants. In: Mortvedt JJ, Cox FR, Shuman LM, \& Welch RM (Eds.). Micronutrients in Agriculture, $2^{\text {nd }}$ Edition. pp. 329-370. Soil Science Society of America Wisconsin.

Handoko S. 2014. Kajian Epidemi Penyakit Kanker Batang Duku di Provinsi Jambi. Disertasi. Universitas Gadjah Mada.

Huber DM \& Jones JB. 2013. The role of magnesium in plant disease. Plant Soil. 368(1-2): 73-85.
Kim KD, Nemec S, \& Musson G. 1997. Effects of composts and soil amendments on soil microflora and Phytophthora root and crown rot of bell pepper. Crop Prot. 16(2): 165-172.

Messenger BJ, Menge JA, \& Pond E. 2000. Effects of gypsum on zoospores and sporangia of Phytopthora cinnamomi. Plant Dis. 84(6): 617621.

Núñez-Zofío M, Larregla S, \& Garbisu C. 2011. Application of organic amendments followed by soil plastic mulching reduces the incidence of Phytophthora capsici in pepper crops under temperate climate. Crop Prot. 30(12): 1563-1572.

Prigigallo MI, Mosca S, Cacciola SO, Cooke DEL, \& Schena L. 2011. Molecular analysis of Phytophthora diversity in nursery-grown ornamental and fruit plants. Plant Pathol. 64: 1308-1319.

Rangarajan A, McGrath MT, \& Moyer D. 2003. Evaluation of Composts for Managing Phytophthora capsici. New York State IPM Program, New York.

Sarwar M. 2011. Effects of zinc fertilizer application on the incidence of rice stem borers (Scirpophaga species) (Lepidoptera: Pyralidae) in rice (Oryza sativa L.) crop. J. Cereals Oilseeds. 2(5): 61-65.

Sims DA \& Gamon JA. 2002. Relationships between leaf pigment content and spectral reflectance across a wide range of species, leaf structures and developmental stages. Remote Sens. Environ. 81(2-3): 337-354.

Walker SJ \& Bosland PW. 1999. Inheritance of Phytophthora root rot and foliar blight resistance in pepper. J. Amer. Soc. Hort. Sci. 124(1): 1418.

Wen Z, Liao W, Liu C, \& Chen S. 2007. Value-added products from animal manure. In: Yang S (Ed.). Bioprocessing for Value-Added Products from Renewable Resources. pp. 629-651. The Netherlands Columbus. 